\title{
Pemicu Lunturnya Nilai Pancasila Pada Generasi Milenial
}

\author{
Devyanne Oktari, Dinie Anggraeni Dewi \\ Universitas Pendidikan Indonesia Kampus Daerah Cibiru Pendidikan Guru Sekolah Dasar \\ Email: Devyanneoktr@upi.edu ’ dinieanggraenidewi@upi.edu
}

\begin{abstract}
This study intends to describe the decline in the value of Pancasila in this millennial era, and about the lifestyle and character development of Indonesian youth, especially for vulnerable millennials aged 17 to 20 years. At the same time, in the era of globalization, foreign culture entering Indonesia, which is considered normal, has greatly influenced aspects of the life of the Indonesian nation, especially the millennial generation, which should be the next generation of the nation. Currently they are starting to forget and perceive local culture as a bad thing, even if the local culture itself is based on the values of Pancasila, it is already considered outdated, the application of Pancasila values has long changed, and is gradually getting more worried about progress. science and technology. The attitude of individualism is more prominent than when dealing with other people or socializing. The purpose of writing this scientific journal is to re-apply the values contained in Pancasila to the current millennial generation.
\end{abstract}

Keywords: Pancasila values, millennial generation, character, globalization. 


\begin{abstract}
Abstrak
Penelitian ini bermaksud untuk mendeskripsikan penurunan nilai Pancasila Di era milenium ini, dan tentang pola hidup dan penanaman karakter pemuda Indonesia, khususnya bagi kaum milenial yang rentan berusia antara 17 hingga 20 tahun. Bersamaan dengan itu, pada era globalisasi, budaya barat masuk dan berkembang di Indonesia dan sudah dianggap sebagai hal yang lumrah, sudah sangat mempengaruhi aspek kehidupan bangsa Indonesia khususnya generasi milenial yang seharusnya menjadi generasi penerus bangsa. Mereka perlahan mulai meninggalkan dan menganggap budaya lokal sebagai hal yang buruk, kalaupun budaya lokal itu sendiri berlandaskan nilai-nilai Pancasila, sudah dianggap sebagai hal yang ketinggalan zaman, Penerapan nilai-nilai Pancasila telah lama berubah, dan berangsurangsur semakin mengkhawatirkan dengan kemajuan ilmu pengetahuan dan teknologi. Sikap individualisme lebih menonjol dibandingkan saat berhadapan dengan orang lain ataupun bersosialisasi. Tujuan penulisan jurnal ilmiah ini adalah untuk mengaplikasikan kembali nilai yang ada dalam Pancasila kepada generasi milenial saat ini.
\end{abstract}

Kata kunci: globalisasi, nilai pancasila, karakter, generasi milenial. 


\section{PENDAHULUAN}

Perkembangan generasi 1.0 Revolusi Industri (permulaan tahun pertama 1800), menandai penemuan mesin uap. Semua yang tadinya berasal dari tenaga manusia terutama pria berubah menjadi dengan mesin. Revolusi Industri pada seri 2.0 (dimulai tahun 1900) setelah ditemukannya listrik, banyak peralatan di pabrik yang tergantikan dengan listrik. Revolusi Industri 3.0 (dimulai pada tahun 1970) menemukan logika yang dapat diprogram kontrol (PLC), rangkaian elektronik yang dapat mengendalikan sebuah mesin. Revolusi Industri 4.0 (dimulai tahun 2000) mengadopsi transaksi pengolahan data dalam jumlah besar, pabrik pintar. Revolusi Industri 4.0 akan terus berkembang dan terus berkembang secara kontinuitas.

Saat ini kita sedang berada pada era revolusi industri 4.0 yang menempatkan segala nya dengan dibantu oleh keberadaan teknologi, umat manusia berada di ambang revolusi teknologi yang berkelanjutan. Itu secara mendasar akan mengubah hidup kita, pekerjaan dan cara kita bergaul satu sama lain. Globalisasi telah memasuki Indonesia tanpa henti. Dibarengi perkembangan teknologi yang bertambah maju, era revolusioner industri 4.0 menekankan ekonomi digital, kecerdasan buatan, pengolahan data besar, robot, dan lain sebagainya.

Dampak serius dari era ini adalah transformasi fungsi pekerjaan di masyarakat. Saat ini, marak pekerjaan yang telah dihilangkan atau digantikan oleh robot atau sistem otomatis. Tentunya ke depan, dengan perkembangan teknologi digital, kita akan merasakan lebih banyak kejutan. Tahun ini akan lebih jelas lagi. Salah satu buktinya adalah bahwa anak-anak yang seharusnya bermain di alam terbuka kini lebih asyik bermain dengan smartphone. Apakah mereka bermain game online ataupun media sosial.

Secara spesifik, penyebab turunnya nasionalisme juga patriotism pada generasi penerus bangsa yakni salah satunya karena berkembangnya era globalisasi, yang menyimpan dampak negatif disamping dampak positif yang diperoleh. Nasionalisme juga patriotisme merupakan bagian penting bagi negara juga bagi kehidupannya. Dibandingkan dengan budaya Indonesia, banyak anak muda yang menyukai budaya negara lain bisa membuktikan hal tersebut. Misalnya, generasi penerus bangsa lebih menganggap produk buatan asal luar negeri lebih baik daripada produk dalam negeri dan lebih menyukao memakai pakaian minim daripada memakai baju batik yang mencerminkan budaya Indonesia.

Globalisasi berasal dari kata globe / global yang bermakna bola dunia atau universal, namun makna atau arti globalisasi dapat berbeda sebagaimana sudut pandang orang yang melihatnya, berikut makna dan arti globalisasi dari beberapa sudut pandang. Menurut Prof. Dr. Selo Soemardjan (pelopor Fakultas Ilmu Pengetahuan Kemasyarakatan/FISIP), globalisasi ialah suatu proses terbentuknya sistem organisasi dan komunikasi antar masyarakat dunia dalam mengikuti sistem juga kaidah tertentu.

Hal tersebut sangat mengkhawatirkan untuk kelangsungan hidup para generasi penerus bangsa yang akhir-akhir ini sedang tergerus oleh dilema perubahan moral dan sikap, karena terbelenggu oleh aliran arus globalisasi, maka dari itu pengembangan karakter sangat penting untuk kemajuan suatu negara, saya mengutip sebuah telaah pustaka mengenai hal yang kian marak terjadi 
pada generasi penerus bangsa di Indonesia saat ini.

\section{METODE}

Penelitian ini menggunakan metode pendekatan deskriptif dengan melakukan studi tentang lunturnya nilai Pancasila yang terjadi pada generasi milenial pada sumber yang ada, dengan cara mengumpulkan informasi yang lebih spesifik tentang masalah ini lalu menggunakan informasi berkaitan dengan teori yang diteliti, lalu mengumpulkan dan menggunakan informasi yang berkaitan dengan kursus, metodologi, dan penelitian. Melalui jurnal penelitian, buku dan juga internet.

Tujuan jurnal ini adalah untuk menjelaskan mengapa nilai-nilai Pancasila mulai luntur pada kaum milenial saat ini. subjek dari penelitian ini adalah masyarakat umum yang termasuk dalam generasi milenial juga tidak lupa mahasiswa UPI tertentu. Jenis data yang digunakan dalam penelitian ini adalah data sekunder yang diperoleh dari berbagai sumber yang didapat untuk mendukung pengamatan. Data tersebut berupa laporan dan jurnal yang berkaitan dengan materi yang disampaikan yaitu apa penyebab terjadinya fenomena tersebut dan bagaimana pengaruhnya pada nilai-nilai Pancasila.

\section{HASIL DAN PEMBAHASAN}

Setelah membaca dari beberapa sumber yang didapat juga hasil dari pengamatan yang telah penulis lakukan, mengenai lunturnya nilai Pancasila pada generasi milenial ini sangat berpengaruh kepada kemajuan bangsa dan juga kelangsungan hidup warga negara Indonesia hingga beberapa tahun kedepan, Perjuangan untuk mendapatkan kemerdekaan dari bangsa penjajah sudah berakhir, tetapi tantangan untuk mempertahankan kemerdekaan nya yang belum selesai dan tidak akan selesai sepertinya, karena perkembangan zaman akan terus berlangsung dan tidak dapat dihindari maupun ditolak. Oleh sebab itu mengingat pentingnya peran edukasi dan pembelajaran kepada warga negara republik Indonesia agar dapat memelihara juga mempertahankan semangat juang demi kemerdekaan, rasa kebangsaan juga cinta tanah air.

Perkembangan ilmu pengetahuan dan teknologi Indonesia yang semakin modern, juga Revolusi Industri ke 4.0 yang mulai memasuki Indonesia. Perkembangan ilmu pengetahuan dan teknologi juga tidak terlepas dari nilai budaya dan agama yang menjadi moral bangsa. Contoh nya ialah pada menerapan sila ketiga mengenai persatuan, namun saat ini, masyarakat hidup jauh dari nilai persatuan dan lebih banyak menikmati perkembangan teknologi saat ini untuk mencapai hal yang ia butuhkan maupun inginkan. Pengaruhnya lainnya berkisar dari dalam dan luar masyarakat Indonesia. Pancasila diharapkan dapat eksis sebagai ideologi, dan dapat memperkuat sikap dan karakter masyarakat untuk menerima tantangan zaman.

Pancasila yang mengandung sederet nilai-nilai dasar ideal, merupakan komitmen pada negara, pengakuan negara, dan menjadi dasar pengembangan karakter bangsa Indonesia. Berdasarkan pandangan fungsionalisme struktural, negara multietnis yang dapat dijadikan sebagai nilai yang komprehensif, kesamaan denominator, identitas bangsa, dan nilai-nilai yang dianggap mudah dicapai (nilai ideal) (Kariyadi \& Suprapto, 2017). 
Dengan pesatnya perkembangan ilmu pengetahuan dan teknologi yang di Indonesia, menjadikan terlena nya bangsa yang menjadikan jiwa nilai-nilai Pancasila juga memudar, yang akan membawa hal-hal buruk bagi negara yakni kemerosotan generasi muda di era milenium ini.

Budaya Tradisional Indonesia juga ikut terpengaruh oleh Tren globalisasi saat ini yang berdampak pada perkembangan budaya Indonesia, Pesatnya perkembangan informasi dan telekomunikasi justru menyebabkan kecenderungan menurunnya aspek dalam berbudaya. Lemahnya keinginan masyarakat dalam upaya melestarikan budaya negara sendiri. Budaya Indonesia yang identik ramah, gotong royong, saling membantu dan santun telah tergeser oleh budaya asing, gaya berpakaian remaja Indonesia yang selama ini selalu mengikuti kaidah tata krama mengalami perubahan seiring perkembangan zaman. Di kota besar, remaja putri cenderung mengenakan pakaian minim dan ketat untuk memamerkan bagian tubuh tertentu. Budaya berpakaian minim ini diadopsi dari film dan majalah asing yang disulap menjadi sinetron Indonesia

Penulis melakukan observasi di berbagai bidang seperti lingkungan kampus UPI, Unisba, komunitas, cafe gathering ataupun mahasiswa di sekitar kota bandung. Dalam pengamatan penulis, sikap yang ditunjukkan pada beberapa masyarakat dan rekan mahasiswa menunjukkan sikap tidak mencerminkan nilai-nilai Pancasila dalam kehidupan sehari-hari nya.

Seringnya terjadi sikap individualitas saat berkumpul di satu tempat, doimana semua orang hanya fokus pada gadget yang dimilikinya. Kalaupun ada teman di sebelahnya, mereka tetap main gadget, sama seperti tidak peduli dengan orang di sekitarnya.
Seringkali kelompok yang tidak membela hak justru membela kesalahan karena kaki tangannya yang terlibat dalam kasus tersebut melakukan kesalahan dan terkesan tidak banyak bersikap. Artinya, sikap lebih mengutamakan orang lain dalam pergaulan sosial, sikap ini akan saling menemani dan memilih berteman. Kemudian, kesadaran akan rasa tanggung jawab menjaga lingkungan sekitar sudah memudar, rasa gotong royong berangsur-angsur melemah, kelompok yang merusak fasilitas umum, terjadinya $\mathrm{KKN}$, dan seringnya terjadi pelanggaran peraturan lalu lintas.

Lalu marak terjadinya demo karena banyak rakyat yang merasa diperlakukan tidak adil oleh pemerintah, contohnya pada kasus demo besar yang terjadi pada 05 Oktober 2020, banyak mahasiswa, buruh dan juga masyarakat yang turun kejalan karena merasa tidak diperhatikan haknya sebagai warga negara Indonesia, pada peristiwa tersebut ada beberapa korban jiwa yang tewas demi memperjuangkan hak nya.

Upaya kita dalam tujuan menumbuhkan sikap lebih selektif dalam perkembangan zaman juga globalisasi dan mengadopsi aspek positif dari proses globalisasi. Salah satu aspek yang penting dalam upaya ini yakni orang tua. Orang tua merupakan orang yang berperan penting dalam mendidik anak, orang tua diharapkan mampu memahami juga memilah kiranya dampak positif dan dampak negatif yang disebabkan dari globalisai dari hal yang terkecil, sehingga anak tidak akan tertelan oleh pengaruh negatif globalisasi. Sungguh hal yang sangat memprihatinkan disisi lain kesalahan tidak sepenuhnya berada pada pihak generasi milenial ataupun rakyat, namun adapula beberapa kesalahan di dalam pemerintahan. 
Pemahaman masyarakat tentang nasionalisme sekaligus patriotisme memudar oleh paham globalisme. Persaingan ekonomi yang sengit dan kondisi globalisasi telah menimbulkan konflik di beberapa negara. Kondisi seperti itu rupanya terjadi pada semua negara di dunia, termasuk Indonesia, kekuatan modal asing menjadi semakin merajalela, dan skalanya semakin meluas. Tidak lupa dampak globalisasi yang juga menyebabkan konflik antar etnis dan antar agama, hal ini sungguh sangat memprihatinkan.

Nilai karakter nasional semacam pemikiran, perilaku dan melakukan sesuatu yang menunjukkan kesetiaan, peduli dan sangat menghargai terhadap bahasa, materi, sosial, budaya, ekonomi maupun politik negara, mampu menempatkan kepentingan nasional, keperluan di luar kepentingan pribadi dan kelompoknya. Hargai budaya negara sendiri dan lindungi dirinya sendiri, menjaga kekayaan budaya negara, rela berkorban demi nusa bangsa, berprestasi bagi dirinya dan lingkungan sekitar, cinta tanah air, melindungi lingkungan, mematuhi hukum, disiplin dan toleransi keragaman agama. Pendidikan karakter tidak hanya mendorong pembentukan perilaku positif namun disamping itu anak-anak dituntut mampu meningkatkan kualitasnya kognitif maupun kreativitas nya.

Nilai karakter religius mencerminkan keimanan kepada Tuhan Yang Maha Esa yang tercermin pada kehidupan beragama dan berkeyakinan, menghargai perbedaan agama, dan memiliki sikap toleran, hidup rukun bersama pemeluk agama lain. Sifat gotong royong mewujudkan perilaku menghargai semangat gotong royong dan bekerja sama untuk menyelesaikan masalah bersama, menjalin pertukaran dan persahabatan, serta memberikan bantuan kepada masyarakat.
Pendidikan karakter yang menyenangkan agar tiap tindakan dipandu dengan nilai normatif, agar generasi penerus bangsa menghargai norma-norma yang ada dan menjadikan perilakunya berorientasi pada masyarakat, dengan rasa percaya diri juga memiliki keberanian, sehingga terbentuk menjadi pribadi yang kuat, tidak mudah goyah, takut berisiko dalam situasi tertentu yang baru.

Pentingnya pendidikan karakter dapat diuji dalam konteks kemajuan ciri-ciri dari angkatan kerja yang dibutuhkan oleh negara dan jaman yang akan dating, dalam konteks kemajuan suatu negara, berbagai penelitian menunjukkan bahwa kemajuan suatu negara tidak lepas dari kuatnya karakter dan budaya masyarakatnya. Kemajuan suatu negara tidak lepas dari penanaman nilai-nilai uniknya. Negara telah menjadikan karakternya sebagai modal persaingan di era globalisasi.

Karakter bangsa yang menjadi fondasi yang kokoh bagi modernisasi dan pembangunan, tidak tunduk pada penetrasi dan kekalahan nilai-nilai budaya asing, melainkan menjadi kekuatan transformatif yang kuat untuk kemajuan. Oleh karena itu, menghidupkan kembali nilai-nilai unik ciri khas bangsa Indonesia adalah sarana kemajuan kita di masa depan, dan ini merupakan tanggung jawab kita bersama.

Pancasila adalah sistem ideologi bangsa Indonesia, landasan negara dan bangsa, dan sumber dari segala aturan eksistensi bangsa Indonesia.Pancasila adalah cita-cita, landasan, sudut pandang, dan pemahaman berbangsa. Sebagai ideologi negara, Pancasila merupakan tujuan bersama yang dicapai oleh negara Indonesia dalam pembangunan negara, yaitu membangun masyarakat adil dan makmur dengan pemerataan materi dan 
jiwa. Pancasila juga merupakan wadah pemersatu Indonesia yang bertujuan untuk menciptakan suasana nasional yang aman, tentram, tertib dan bersemangat, serta mewujudkan perdamaian yang bebas, bersahabat, dan tertib. Kemampuan menahan perpecahan negara bukan tanpa alasan. Pasalnya, bangsa Indonesia sudah memiliki sarana untuk mempersatukan negara (kohesi nasional) yang secara alamiah terbentuk dari nilai-nilai luhur bangsa Indonesia.

Sikap nasionalisme harus dibarengi dengan upaya memahami Pancasila yang mengandung nilai-nilai luhur bangsa Indonesia. Pancasila merupakan landasan dan gaya hidup bangsa Indonesia yang mengandung nilai-nilai kebangsaan yang harus ditanamkan sebagai penerus bangsa di kalangan anak-anak. Dengan memahami Pancasila maka ciri kebangsaan dapat dikembangkan. Nasionalisme tidak terlepas dari dorongan untuk mencintai tanah air dan negerinya sendiri, karena dibutuhkan pendidikan plant personality dari semua kalangan, terutama generasi milenial yang merupakan generasi penerus bangsa.

Menurut (Sulistyarini, 2015), fungsi Pancasila sebagai ideologi memberikan arahan dan landasan bagi pembangunan, sekaligus memberikan kesempatan kepada siswa untuk tidak memisahkan siswa dari lingkungan sosial budaya masyarakat dan budaya bangsa. Lingkungan sosial budaya negara adalah Pancasila. Oleh karena itu, pendidikan budaya dan karakter bangsa harus berlandaskan nilai-nilai Pancasila.

Menurut Rencana Aksi Pendidikan Karakter Nasional 20102014 oleh Kementerian Pendidikan, penekanan pada pendidikan karakter adalah pendidikan nilai, pendidikan karakter, dan pendidikan moral. Hal ini bertujuan untuk mengembangkan kemampuan siswa agar setiap hari dapat mengambil keputusan baik dan buruk dengan sepenuh hati, menjaga keputusan yang baik, dan menyadari indahnya hidup.

Menurut Kupperschmidt generasi atau biasa disebut gen yakni sekelompok orang yang sama dapat dilihat berdasarkan tahun lahir, umur, lokasi dan kesamaan peristiwa kehidupan untuk menentukan kelompoknya, kelompok ini memiliki pengaruh penting dalam tahap pertumbuhannya.

Menurut artikel Yuswohady dalam "Millennium Trends", generasi millennial adalah generasi yang lahir dari tahun 1980-an hingga awal 2000an, biasa disebut generasi Y, Generasi Net, Generasi WE, Generasi Boomerang, Generasi Peter Pan, dll. Alasan mereka disebut milenial karena mereka adalah generasi yang hidup di pergantian milenium. Bersamaan dengan itu, di era sekarang ini, teknologi digital sudah mulai merambah segala aspek kehidupan. Generasi ini menggunakan banyak teknologi pesan instan, seperti email, SMS, pesan instan, dan media sosial, seperti Facebook dan Twitter, Instagram dan lain sebagainya.

Smartphone merupakan buah dari teknologi, perangkat yang sangat erat kaitannya dengan kehidupan sehari-hari saat ini. alat ini kemudian menjadi alat untuk menunjang berbagai aktivitas, hobi dan segala aspek kehidupan. Smartphone lahir dari perkembangan zaman yang terus berkembang seiring jalan, namun hal tersebut juga menjadikan nilai Pancasila perlahan-lahan terkikis dan melemah di kalangan anak muda, dan dengan cepat terpengaruh oleh berbagai informasi yang sumber nya belum jelas. Banjir informasi scam bahkan dapat 
menyebabkan satu orang bertengkar dengan orang lain.

Hal tersebut juga mempengaruhi karakter para generasi penerus bangsa, yang seharusnya memiliki jiwa nasionalisme dan patriotisme namun berubah menjadi generasi yang acuh pada negara nya sendiri, tidak luput dari peran pendidikan dan juga lingkungan sekitar.

Generasi muda yang memiliki sikap nasionalisme, patriotisme, dan potensi akan mampu memenuhi potensinya, mampu menghadapi semua tantangan, dan memberikan solusi atas berbagai permasalahan yang ia dihadapi, namun ada pula kaum muda telah melakukan hal yang membuat negara ini semakin buruk, dan banyak di antaranya telah terjadi. Fakta menunjukkan bahwa remaja terlibat dalam berbagai peristiwa, seperti kejahatan, narkoba, alkohol, pergaulan bebas, pelecehan seksual, dan perkelahian pelajar, situasi ini sangat mengkhawatirkan. Potret dari berbagai peristiwa menunjukkan bahwa anak muda kurang memperhatikan nasib negaranya, dan seperti apa masa depan bangsa dan negara Indonesia nantinya. Tantangan juga permasalahan yang begitu kompleks sehingga tidak dapat dihadapi oleh generasi kita, oleh karena itu mewujudkan cita-cita kemajuan bangsa hanya akan menjadi anganangan.

\section{SIMPULAN DAN SARAN}

Sikap nasionalisme harus dibarengi dengan upaya memahami Pancasila. Sebagai landasan dan pedoman hidup bangsa Indonesia yang mengandung nilai-nilai kebangsaan, dan harus menjadi generasi penerus bangsa yang dapat menanamkan nilainilai kebangsaan itu kembali kelak kepada generasi penerus bangsa selanjutnya. Dengan memahami Pancasila maka ciri kebangsaan dapat dikembangkan. Nasionalisme tidak terlepas dari keinginan untuk mencintai bangsa dan negara sendiri, karena diperlukan untuk menanamkan pendidikan karakter pada setiap orang. Indonesia saat ini menghadapi era globalisasi ekonomi yang kompleks.

Namun tidak semua masyarakat mengetahui konsekuensi atau akibat logis dari fenomena ini, terlihat jelas bahwa banyak generasi manusia telah tergerus oleh efek negatif dari era globalisasi saat ini. Bersamaan dengan itu, siap atau tidaknya negara ini harus mampu menghadapi dan menjawab tantangan global agar kondisi ekonomi tidak semakin memburuk.

Oleh karena itu, pendidikan Pancasila dianggap penting dan harus diinternalisasaikan ke dalam mata kuliah perguruan tinggi, memperkuat pengetahuan mahasiswa mengenai makna Pancasila. Agar dapat menjadi warga negara yang baik, bertanggung jawab, mahasiswa harus mampu menyelesaikan masalah, masalah nya sendiri maupun komunitas, konflik antar pribadi dan antar kelompok dilakukan secara damai dan demokratis, dalam hal ini pendidikan kewarganegaraan bisa masuk dan dikembangkan mengenai keterampilan pemecahan masalah siswa, termasuk konflik.

Karakter bangsa diartikan sebagai ciri kepribadian yang relatif tetap, cara hidup, cara berpikir, perilaku, dan bertindak sesuai dengan nilai luhur seseorang berasal dari budaya nasional Indonesia penuh dengan nilai-nilai Pancasila, fungsifungsi Pancasila dari perspektif kehidupan pancasila juga jiwa dan kepribadian nasional pembangunan karakter sedang berkembang "Jiwa" negara. Pendidikan karakter ssebagai 
perwujudan amanah Pancasila dan UUD 1945.

Generasi muda yang memiliki rasa nasionalisme, patriotisme, dan potensi penuhnya akan mampu memenuhi segala potensinya, mampu menghadapi segala tantangan, dan memberikan solusi atas berbagai permasalahan yang dihadapi di era globalisasi, namun ada pula kaum muda telah melakukan hal yang membuat negara ini semakin buruk, dan banyak di antaranya telah terjadi. Fakta menunjukkan bahwa remaja terlibat dalam berbagai peristiwa, seperti kejahatan, narkoba, alkohol, pergaulan bebas, pelecehan seksual, dan perkelahian pelajar, situasi ini sangat mengkhawatirkan. Potret dari berbagai peristiwa menunjukkan bahwa anak muda kurang memperhatikan nasib negaranya, dan seperti apa masa depan bangsa dan negara Indonesia nantinya. Tantangan dan permasalahan yang begitu kompleks sehingga tidak dapat dihadapi oleh generasi kita, oleh karena itu mewujudkan cita-cita kemajuan bangsa hanya akan menjadi anganangan.

Dalam sekolah maupun
dilingkungan sehari-hari. Mampu
lingkungan sosial seharidupan
membangun warga negara Indonesia
yang baik, yaitu warga negara yang
beriman dan bertaqwa kepada Tuhan
Yang Maha Esa, berjiwa mandiri,
memahami dan menjalankan hak juga
kewajibannya dengan kepekaan baik,
memiliki rasa kebangsaan dan cinta
tanah air, serta memiliki rasa
kebangsaan. dan tanggung jawab sosial,
pribadi yang demokratis, mampu
menghargai perbedaan ras, budaya dan
agama, mampu berpikir kritis,
sistematis, inovatif dan mampu
mengambil keputusan.

Pendidikan tidak hanya sekedar membentuk orang pintar, tapi juga berkarakter dan memiliki kepribadian yang baik, agar generasi negeri ini bisa terus bertumbuh dan berkembang. Hal tersebut dilandasi oleh nilai-nilai luhur bangsa dan agama. Dapat disimpulkan dari ini bahwa tugas meningkatkan pendidikan karakter digunakan sebagai dasar dan perisai atau pengontrol untuk milenial pada pembangunan di era yang kompleks atau era globalisasi ini.

Mengingat pentingnya pendidikan kewarganegaraan yang merupakan salah satu jenis pendidikan sekolah sejak awal dimulai dari pendidikan dasar hingga pendidikan tinggi. Pada saat yang sama, pendidikan kewarganegaraan tidak hanya di lingkungan, tetapi juga memiliki cakupan yang lebih luas dari pada pendidikan lainnya. Tidak hanya sekolah formal, tetapi juga pendidikan informal dan nonformal. Landasan kewarganegaraan didasarkan pada konsep, yaitu keberadaan ilmu pengetahuan disiplin ilmu lainnya, seperti ilmu sosial, politik, dan hukum. Selain itu, warga negara menerima kursus formal dan informal dari pendidikan dasar. Menengah atau lanjutan, dan memiliki dasar yudisial formal, yaitu dasar hukum warga negara dalam UUD 1945 dan UU No. 20 Tahun 2003.

Terdapat beberapa definisi dari Pendidikan Kewarganegaraan, yaitu : Civic Education, yaitu proses pembelajaran dan pembinaan dalam upaya mengembangkan perilaku warga negara yang baik dalam lingkungan pendidikan . lalu ada Citizenship Education, yaitu upaya pembinaan warga negara yang cerdas dan baik melalui lingkungan informal, formal, dan nonformal. Dan ada Civics, yaitu kajian keilmuan kewarganegaraan yang isinya mempelajari hubungan antara individu dengan individu serta individu dengan negara. Mata pelajaran Pkn mengalami berbagai perkembangan 
konten dan juga perubahan nama mulai dari tahun 1960 hingga akhirnya sekarang ditetapkan sebagai Pendidikan Kewarganegaraan. Menjadi smart and good citizen yaitu menjadi warga negara yang sesuai dengan karakter negaranya. Sebagaimana mewujudkan cita-cita tersebut dibuatlah tujuan dan sasaran pembelajaran PKn yaitu sebagai berikut Civic knowledge: berkaitan dengan pengetahuan kewarganegaraan. Civic skills: berkaitan dengan keterampilan, ketika telah paham dan tahu, kemudian mengimplementasikan secara nyata Civic dispositions: berkaitan dengan watak warga negara. Civic Competence: berkaitan dengan kompetensi yang dimiliki warga negara. Civic Commitment: berkaitan dengan komitmen sebagai warga negara yang baik. Civic Confidence: berkaitan dengan keyakinan kewarganegaraan.

Visi juga misi dari pembelajaran Pkn ini yakni sebagai Sumber nilai dan pedoman dalam pengembangan dan penyelenggaraan program studi guna mengantarkan mahasiswa memantapkan kepribadiannya sebagai manusia Indonesia seutuhnya. Misi yang terkandung untuk membantu mahasiswa memantapkan kepribadiannya agar secara konsisten mampu mewujudkan nilai-nilai dasar keagamaan, kebudayaan, rasa kebangsaan, dan cinta tanah air sepanjang hayat dalam menguasai, menerapkan dan mengembangkan ilmu pengetahuan, teknologi dan seni yang dimilikinya dengan rasa tanggung jawab.

\section{DAFTAR PUSTAKA}

Ginting, H. 2017. Peranan Pancasila Dalam Menumbuhkan Karakter Bangsa Pada Generasi Muda. In Prosiding
Seminar Nasional Tahunan Fakultas Ilmu Sosial Universitas Negeri Medan. Diakses pada tanggal 22 Maret 2021. http://digilib.unimed.ac.id/27458 I

Putra, Yanuar Surya, 2016. "Theoritical Review: Teori dan Perbedaan Generasi”, Among Makarti, Vol.9. Diakses pada tanggal 22 Maret 2021. https://ejournal.iaitabah.ac.id/index.php/musthofa/a rticle/download/364/294

Agus, A. A. 2016. Relevansi Pancasila Sebagai Ideologi Terbuka di Era Reformasi. Jurnal Office. Diakses pada tanggal 22 Maret 2021. https://docplayer.info/47090780Relevansi-pancasila-sebagaiideologi-terbuka-di-erareformasi-a-aco-agus-fakultasilmu-sosial-universitas-negerimakassar.html

Winarno, Budi, 2008. Globalisasi Peluang atau Ancaman bagi Indonesia, Jakarta Erlangga. Diakses pada tanggal 22 Maret 2021. https://books.google.co.id/books ?id=9V4v_Ooj8dYC\&printsec $=\mathrm{f}$ $\underline{\text { rontcover } \& h l=i d \& \text { source }=g b s \_a t}$ $\underline{\mathrm{b}}$

Cholisin. 2011. Pengembangan

Karakter Dalam Materi

Pembelajaran PKn. Makalah disampaikan pada kegiatan MGMP PKn SMP Kota Yogjakarta. Diakses pada tanggal 23 Maret 2021. http://staffnew.uny.ac.id/upload /131474282/pengabdian/PENGE MBANGAN+ KARAK TER+DALAM+MATERI+PE MBELAJARAN+PKn.pdf

Yudistira. 2016. Aktualisasi \& Implementasi Nilai -Nilai Pancasila dalam 
Menumbuhkan Kembangkan

Karakter Bangsa. di Seminar

Nasional Hukum.

Diakses pada tanggal 23 Maret

2021.

https://www.semanticscholar.org

/paper/Aktualisasi\%26Implement asiNilaiNilaiPancasilaYudistira/f a73794a0a9f2f270f4948e904e97 2b32b4eccc3

Doni Koesoema A. 2009. Pendidik Karakter. Jakarta: Kompas Gramedia. Diakses pada tanggal 23 Maret 2021. https://edukasi.kompas.com/rea d/2010/02/11/10244662/pendidik an.karakter.inte gral.?p age $=\mathrm{al}$

Darmawan. 2018. Revitalisasi Pancasila Sebagai Pedoman Hidup Bermasyarakat di Era Globalisasi. Universitas Islam Negeri Raden Intan Lampung. Diakses pada tanggal 23 Maret 2021.

http://repository.radenintan.ac.id/ 3422/

Sulistyarini. 2015. Pengembangan

Karakter Berbasis Pancasila

Melalui Pendidikan

Kewarganegaraan. Jurnal Bhinneka Tunggal Ika. Diakses pada tanggal 23 Maret 2021. https://garuda.ristekbrin.go.id/do cuments/detail/513466

Gunawan, Heri. 2012. Pendidikan

Karakter Konsep dan

Implementasi. Alfabet:

Bandung. Diakses pada tanggal

23 Maret 2021.

https://opac.perpusnas.go.id/De tailOpac.aspx?id=814196

Soegeng. 2015. Etika Pancasila Nilai-

Nilai Pembentuk Karakter.

Magnum Pustaka Utama:

Yogyakarta.

Depdiknas. 2003. UU No. 20 Tahun 2003 Tentang Sistem Pendidikan Nasional. Diakses pada tanggal 23 Maret 2021. http://pendis.kemenag.go.id/file /dokumen/uuno20th2003ttgsisdik nas.pdf

Anggaraini, D. dkk. 2020. Pengamalan Nilai-Nilai Pancasila Bagi

Generasi Milenial. JISoP.

Universitas Islam Malang.

Diakses pada tanggal 23 Maret 2021.

http://riset.unisma.ac.id/index.ph $\mathrm{p} / \mathrm{JISoP} /$ article/view/4945

Kementerian Pendidikan Nasional.

2010. Rencana Induk

Pengembangan Pendidikan

Karakter Bangsa. Jakarta:

Kementerian Pendidikan

Nasional. Diakses pada tanggal

24 Maret 2021.

https://jurnaldikbud.kemdikbud

.go.id/index.php/jpnk/article/dow nload $/ 45 / 42$

Bunyamin Maftuh. 2008. Internalisasi

Nilai-Nilai Pancasila dan

Nasionalisme Melalui

Pendidikan Kewarganegaraan.

Bandung. Jurnal Edukasi. Upi.

Edu. Diakses pada tanggal 23

Maret 2021. http://file.upi.edu/Direktori/JU

RNAL/EDUCATIONIST/Vol._I

I_No. 2-

Juli_2008/7_Bunyamin_Maftu

h_rev.pdf

Priyambodo, A. B. 2017.

Implementasi Pendidikan

Karakter: Semangat

Kebangsaan dan Cinta Tanah

Air Pada Sekolah Berlatang

Islam di Kota Pasuruan. Jurnal

Sains Psikologi. Diakses pada

tanggal 23 Maret 2021.

http://journal2.um.ac.id/index.p hp/JSPsi/article/view/487. 